\title{
COVID-19 Prevention Practices and Associated Factors Among Farmers in Peri-Urban Areas of Northeastern Ethiopia
}

\section{Leykun Berhanu (D) \\ Gete Berihun (D) \\ Zebader Walle (iD) \\ Daniel Teshome (iD) \\ Adinew Gizeyatu \\ Masresha Abebe \\ Seada Hassen \\ Ayechew Ademas (D) \\ Birhanu Wagaye \\ Metadel Adane (D)}

'Department of Environmental Health Science, College of Medicine and Health Sciences, Wollo University, Dessie, Ethiopia; ${ }^{2}$ Department of Social and Public Health, College of Health Sciences, Debre Tabor University, Debre Tabor, Ethiopia; ${ }^{3}$ Department of Anatomy, College of Medicine and Health Sciences, Wollo University, Dessie, Ethiopia; ${ }^{4}$ Department of Public Health Nutrition, School of Public Health, College of Medicine and Health Sciences, Wollo University, Dessie, Ethiopia
Correspondence: Leykun Berhanu

Email leyberhanuwu.edu.et@gmail.com
Background: COVID-19 is a global health threat due to its rapid spread and ability to kill millions of people. The majority of pandemic-fighting approaches rely on prevention activities, which can be influenced by a variety of factors. Farmers are more vulnerable to COVID-19, so evaluating existing prevention practices and associated factors is critical to prevent the COVID-19 pandemic.

Objective: To assess COVID-19 prevention practices and associated factors among farmers in peri-urban areas of Northeastern Ethiopia.

Methods: A community-based cross-sectional study design was conducted among 409 selected farmers. Data were collected using face-to-face interviews and on-the-spot-observational checklist. Data were analyzed using bivariable logistic regression model at $95 \% \mathrm{CI}$ (confidence interval). During the bivariable analysis (crude odds ratio [COR]), varibales having a $p$-value of less than 0.250 were included into the multivariable analysis (adjsuted odds ratio $[\mathrm{AOR}]$ ). Factors associated with COVID-19 preventive practices were determined using a multivariable analysis at a $p$-value of 0.050 .

Results: Of 409 participants, 206 (63.6\%), 157 (38.4\%), and 117 (28.6\%) of them had satisfactory knowledge, positive attitude, and good prevention practices about COVID-19, respectively. Age of the farmers with greater than or equal to 45 years (AOR: $3.2 ; 95 \% \mathrm{CI}$ : 1.7-6.1), educational status of secondary school and above (AOR: 3.1; 95\% CI: 1.4-6.6), and income level of having greater than or equal to 2,001.00 Ethiopian birr (ETB) (AOR: 1.9; 95\% CI: 1.1-3.4) were all found to be significantly associated with the COVID-19 prevention practices.

Conclusion: Even though the majority of farmers had satisfactory knowledge, a considerable proportion of them had a negative attitude and poor COVID-19 prevention practices. Age, educational status, and income level are factors associated with COVID-19 prevention practices. Hence, health education should be given to improve the farmers' knowledge, attitudes and prevention practices to minimize the risk of COVID-19 among farmers in semi-urban areas of northestern Ethiopia.

Keywords: COVID-19, Dawa Chefa District, Peri-urban Areas, Farmers, Northeast Ethiopia

\section{Introduction}

COVID-19 is a virus that originated in Wuhan, China, and is more infectious than the Coronavirus that causes Severe Acute Respiratory Syndrome (SARS) and Middle East Respiratory Syndrome (MERS). ${ }^{1}$ Evidence indicate that the virus is carried by birds and mammals, with humans being particularly vulnerable to infection and 
transmission. $^{2,3}$ COVID-19 is transferred largely by droplets from infected people coughing, sneezing, or speaking, as well as by touching a contaminated surface and then contacting the eyes, nose, or mouth without washing hands. ${ }^{4,5}$

COVID-19 manifests itself as cough, fever, malaise, weakness, and shortness of breath. The new virus has sparked widespread alarm around the world because of its great potential for quick spread and the fact that it can be deadly. ${ }^{6,7}$ COVID-19 in its later stage resulted in respiratory distress syndrome, septic shock, hemorrhage, and coagulation malfunction. ${ }^{8}$

Hand washing, wearing a face mask, maintaining a safe physical distance, keeping the space ventilated, avoiding crowded areas, covering the nose and mouth while coughing or sneezing, avoiding direct contact with animals and suspected areas of coronavirus infections, and avoiding the intake and handling of raw meat to prevent cross-contamination are among the COVID-19 prevention practices suggested by the World Health Organization (WHO). ${ }^{9}$

COVID-19 prevention efforts are said to be influenced by group awareness and mindset, according to researchers. ${ }^{10,11}$ For example, the SARS outbreak in China demonstrated how a lack of information and mindset can make disease prevention more difficult. ${ }^{12}$ People's desire to support government attempts to combat the pandemic is also substantially influenced by their level of awareness, and having more knowledge is highly associated to a good attitude regarding COVID-19 prevention methods. ${ }^{13}$

Despite taking a number of prevention measures, numerous countries, including Ethiopia, are still unable to contain the pandemic. Many African continents, including Ethiopia, are seeing an increase in infection rates. As of March 23, 2021, the WHO reported that more than 120 million individuals had been infected and more than 2.7 million had perished. In Africa, more than 3 million people have been affected. Since March 23, 2021, when the first incidence of COVID-19 was discovered in Ethiopia on March 13, 2020, more than 190,000 people have been infected and over 2500 people have died. ${ }^{14}$

Effective infection prevention and control practices must be implemented at the global, national, and individual levels to combat the COVID-19 pandemic, which necessitates sufficient knowledge of the etiology, transmission, and various community responses to the pandemic, as well as a positive mindset, to correctly implement the prevention practices. ${ }^{13,15,16}$ The best example was during the Ebola pandemic, when research on awareness, attitude, and practice (KAP) helped to establish preventive techniques. The data support the theory that a lack of understanding about the diseases contributes to an increase in the number of cases. This means that community awareness, thinking, and prevention activities helps in containing the outbreak and minimizing its impact on public health, social, economic, and political issues. ${ }^{17}$

Several studies have focused on COVID-19 prevention practices in the general population, healthcare workers, and those with chronic illnesses. However, as per our knowledge, so far no research has been done to determine the prevention practices and related factors among vulnerable populations in peri-urban areas such as farmers, who are the backbone of society in low- and middleincome countries, including Ethiopia. Agriculture provides food through harvesting crops including wheat, sugar cane, rice, and a variety of other crops. Farmers are important for the establishment of a good crop with a fair yield, which they can only supply, thus none of this would be possible without them. The COVID-19 pandemic has had a profound impact on humanity's lifestyle and activities, including agriculture. Food demand and hence food security are significantly impacted as a result of mobility restrictions, reduced purchasing power, and a disproportionate impact on the most vulnerable population groups. According to the Food and Agriculture Organization, COVID-19 has a substantial impact on agriculture in two areas: food supply and demand. These two factors are inextricably linked to food security. ${ }^{18}$

As a result, protecting farmer's health from the COVID-19 pandemic entails enhancing the public's health. Therefore, this study aimed to assess COVID-19 prevention practices and associated factors among farmers in peri-urban areas of Dawa Chefa District, Northeastern Ethiopia.

\section{Methods}

\section{Study Area Description}

The study was conducted in the peri-urban areas of Dawa Chefa District, which consists of four Kebeles (the smallest administrative unit in Ethiopia) of Oromia Special Zone in Amhara region, Northeastern Ethiopia. The district is $326 \mathrm{~km}$ far from Addis Ababa, the capital city of Ethiopia, to Northern Ethiopia. According to the Central 
Statistical Agency (CSA), the population projection of Dawa Chefa district was 150,165 populations composed of 74,687 (49.7\%) male and the remaining 75,478 (50.3\%) female. ${ }^{19}$ Dawa Chefa District is located at a latitude and longitude of $10^{\circ} 43^{\prime} \mathrm{N}$ and $39^{\circ} 52^{\prime} \mathrm{E}$, respectively. The altitude of the area ranges from 1500 to 2300 meters above sea level. Based on the climatic classification, the area is classified under semiarid climatic conditions. The rainfall distribution of the study area has highly seasonal and temporal variations. The predominant production system in this area is mixed crop-livestock farming in which cattle are the most important livestock species. ${ }^{20}$

\section{Study Design and Populations}

A community-based cross-sectional study design was conducted from January 1 to February 15, 2021. The source populations were all farmers in the peri-urban areas of Dawa Chefa District whose age 18 years and above, whereas the study population was all farmers living in the selected peri-urban Kebeles of Dawa Chefa District.

\section{Sample Size Determination and Sampling Procedure}

The sample size was determined using a single population proportion formula. ${ }^{21}$

$$
n=\frac{\left(z_{a / 2}\right)^{2} * p(1-p)}{d^{2}}
$$

Using the assumptions of:

$Z_{\alpha / 2}$ is the standard normal variable value at $(1-\alpha) \%$ confidence level ( $\alpha$ is 0.05 with $95 \%$ CI [confidence interval], $\left.Z_{\alpha / 2}=1.96\right), p$ is an estimate of the expected prevention practices for COVID-19 in Dawa Chefa District taken as a good prevention practice of $50.0 \%$. A proportion of $50.0 \%$ was considered since there had been no previous study conducted in the study area or other similar setting, and $d$ margin of error (5.0\%). Adjusting for a $10 \%$ nonresponse rate, the final sample size was determined to be 422. Of the total four peri-urban Kebeles, two Kebeles were selected randomly. Households with residents aged 18 years and above were selected from each Kebele and study participants were allocated proportionally. A sampling frame was made within households that had at least one resident aged 18 years and above. Households with study participants aged 18 years or above were selected using a systematic sampling technique. When there is more than one eligible participant with the selected household, a simple random sampling technique was used.
From the selected household, if there was no eligible study participant during the first visit, another visit was done on the same day or the next day.

\section{Dependent and Independent Variable Measurement}

The dependent variable of this study was the prevention practices of COVID-19, measured as good or poor and the independent variables were socio-demographic characteristics, presence of training about COVID-19, source of information about COVID-19, knowledge about COVID19 (satisfactory or unsatisfactory), and attitude towards COVID-19 (positive or negative). The outcome variable of good or poor prevention practices was measured using 11 close-ended questions having aresponse of "often, sometimes, and never" with ascore of 2,1 , and 0 points, respectively. The total score ranged from 0 to 22 . Then, the respondents were classified as having good COVID-19 prevention practices if they had amean score of $80 \%$ and above, whereas poor preventive practice for amean score of below $80 \%{ }^{10,22}$ The independent variables of sociodemographic factors of the study participants and source of information, knowledge, and attitude about COVID-19 were measured by self-reporting of the study participants.

\section{Knowledge about COVID-19}

To examine knowledge about COVID-19: 18 close-ended questions were used which had a "Yes, No, and do not know" response. A score of "1" mark was assigned for a correct response and a value of " 0 " to an incorrect and do not know the response. The total score ranged from 0 to 18. If the respondents correctly answered $80 \%$ and above, they classified as having satisfactory knowledge otherwise they classified as having unsatisfactory knowledge. ${ }^{10,16}$

\section{Attitude towards COVID-19}

The attitude of the respondents was assessed using 17 close-ended questions, which had a response of "agree, undecided, and disagree" with a score of 2,1 , and 0 , respectively. The total score ranged from 0 to 34 . Then, participants were classified as having a positive attitude if they score $80 \%$ and above otherwise classified as having a negative attitude towards COVID-19. ${ }^{10,16,22}$

\section{Data Collection and Data Quality Assurance}

A structured close-ended questionnaire was prepared in English language, translated to the local language Amharic, 
and re-translated back to English. The questionnaire had four parts. Part I contains socio-demographic information of the respondents; Part II contains questions prepared to assess the knowledge about COVID-19. Part III comprises questions designed to assess the attitude towards COVID-19 and Part IV includes questions prepared to assess the prevention practices applied by households. Before the beginning of the actual data collection, the questionnaire was pre-tested on $5 \%$ of the sample size. Based on the finding obtained, the necessary correction such as the ordering of the questions, addition of the missed question, removing less important questions, and language editions were done accordingly. The primary investigator gave one-day training for both data collectors and supervisors about the objective of the study, data collection tool, ethical issues and other consideration that has to be clear before the beginning of the actual data collection. The data were collected by five environmental health professionals using face-to-face interviews and observational checklist. During data collection, three master holder public health professionals carried out daily supervision.

\section{Data Processing and Analysis}

The data were entered into EpiData version 4.6 and exported to SPSS version 25.0 software for data cleaning and analysis. Descriptive statistics such as frequency and percentage were calculated to examine the overall distribution of the variables. A binary logistic regression model was used to determine the association between the dependent and the independent variables. All the independent variables, which had a p-value of less than 0.250 from the bi-variable analysis, were entered for multivariable analysis. In the multivariable analysis, a $p$-value of $<0.05$ and AOR (adjusted odds ratio) with 95\% CI was used to measure associations, and variables with $p$-value $<$ 0.05 were assumed statistically significant and associated factors of prevention practices against COVID-19 pandemic. The presence of multicollinearity among independent variables was checked using standard error at the cutoff value of 2 and we found that a maximum standard error of 0.380 , which indicate no multicollinearity. Model fitness was checked using the Hosmer and Lemeshow test and we found a $p$-value of 0.485 .

\section{Results}

\section{Socio-Demographic Characteristics of the Respondents}

The survey was completed by 409 of the 422 respondents, for a response rate of $96.9 \%$. Around half 215
Table I Socio-Demographic Characteristics of Farmers in PeriUrban Areas of Dawa Chefa District, Northeastern Ethiopia, January I to February I5, 202 I $(\mathrm{N}=409)$

\begin{tabular}{|c|c|c|}
\hline Variables & Responses & $\begin{array}{l}\text { Frequency } \\
\text { (\%) }\end{array}$ \\
\hline Sex & $\begin{array}{l}\text { Male } \\
\text { Female }\end{array}$ & $\begin{array}{l}194(47.4) \\
215(52.6)\end{array}$ \\
\hline Age (years) & $\begin{array}{l}18 \text { to } 24 \\
25 \text { to } 34 \\
35 \text { to } 44 \\
\geq 45\end{array}$ & $\begin{array}{l}126(30.8) \\
97(23.7) \\
110(26.9) \\
76(18.6)\end{array}$ \\
\hline Educational status & $\begin{array}{l}\text { Cannot read and write } \\
\text { Can read and write } \\
\text { Primary school (I-8 } \\
\text { grade) } \\
\text { Secondary school (9-12 } \\
\text { grade) }\end{array}$ & $\begin{array}{l}135(33.0) \\
157(38.4) \\
60(14.7) \\
57(13.9)\end{array}$ \\
\hline Marital status & $\begin{array}{l}\text { Single } \\
\text { Married } \\
\text { Divorced }\end{array}$ & $\begin{array}{l}120(29.3) \\
243(59.4) \\
46(11.3)\end{array}$ \\
\hline Religion & $\begin{array}{l}\text { Muslim } \\
\text { Orthodox } \\
\text { Protestant }\end{array}$ & $\begin{array}{l}258(63.1) \\
121(29.6) \\
30(7.3)\end{array}$ \\
\hline $\begin{array}{l}\text { Monthly income level } \\
\text { (ETB) }\end{array}$ & $\begin{array}{l}\leq 499.00 \\
500.00 \text { to } 2,000.00 \\
\geq 2,001.00\end{array}$ & $\begin{array}{l}158(38.6) \\
143(35.0) \\
108(26.4)\end{array}$ \\
\hline Family size & $\begin{array}{l}\leq 5 \\
>5\end{array}$ & $\begin{array}{l}215(52.6) \\
194(47.4)\end{array}$ \\
\hline
\end{tabular}

Abbreviation: ETB, Ethiopian Birr.

(52.6\%) of the respondents were female, and more than one-third $135(33.0 \%)$ of them could not read or write. Less than one-third 108 (26.4\%) of the respondents, had a monthly income of more than or equal to 2,000.00 ETB (Average exchange rate of United States Dollars (USD) to Ethiopia birr was 39.6237 during the study period), and nearly half 194 (47.4\%) of them had a family size of more than five (Table 1).

\section{Presence of Training and Source of Information about COVID-19}

Of 409 study participants, about half 228 (55.7\%) of them received training about COVID-19. About half 199 (48.7\%), 108 (26.4\%), and 198 (48.4\%) of the respondents received information about COVID-19 from their family or friends, social media, and radio or television outlets, respectively (Table 2). 
Table 2 Presence of Training and Source of Information About COVID-19 Among Farmers in Peri-Urban Areas of Dawa Chefa District, Northeastern Ethiopia, January I to February I5, 202 I $(\mathrm{N}=409)$

\begin{tabular}{|l|l|l|}
\hline Variables & Responses & Frequency (\%) \\
\hline $\begin{array}{l}\text { Presence of training about } \\
\text { COVID-19 }\end{array}$ & $\begin{array}{l}\text { Yes } \\
\text { No }\end{array}$ & $\begin{array}{l}228(55.7) \\
181(44.3)\end{array}$ \\
\hline $\begin{array}{l}\text { Receiving information through } \\
\text { family/friends }\end{array}$ & Yes & $199(48.7)$ \\
Receiving information through & Yes & $108(26.4)$ \\
social media & No & $301(73.6)$ \\
\hline $\begin{array}{l}\text { Receiving information through } \\
\text { radio/TV }\end{array}$ & Yes & $198(48.4)$ \\
\hline
\end{tabular}

\section{Knowledge of the Respondents about COVID-19}

The majority 338 (82.6) of respondents were aware of the cause of the COVID-19 pandemic. The majority $354(86.6 \%)$ of respondents said there is no cure for COVID-19, but that supportive care might help them recover, and most 359 (87.8\%) of them were aware of the presence of an effective vaccine. The respondents' average knowledge score was $82.3 \pm 9.6 \%$. According to the mean score value, $63.6 \%$ of the respondents had satisfactory knowledge about COVID-19 (Table 3).

\section{The Attitude of the Respondents towards COVID-19}

About two-thirds $255(62.3 \%)$ of the respondents agreed that avoiding touching the eyes, nose, and mouth would reduce the risk of exposure to COVID-19. Almost similar percentage 253 $(61.9 \%)$ of them agreed that coughing and sneezing into the elbow or within the cloth is a good practice to prevent the spread of COVID-19. About three fourth 294 (71.9\%) of them agreed that proper mask usage should include covering nose, mouth, and chin and almost similar proportion 291 $(71.4 \%)$ of them agreed that staying at home play a significant role in preventing the spread of the pandemic. The overall mean attitude score of the respondents was 77.3 $\pm 9.3 \%$. Nearly two-fifth $38.4 \%$ of the respondents had a positive attitude towards COVID-19 (Table 4).

\section{COVID-19 Prevention Practices of the Respondents}

Nearly half $188(46.0 \%)$ of the respondents often went to a crowded place. About two-thirds $253(61.9 \%)$ of the
Table 3 Knowledge of farmers about COVID-19 in Peri-Urban Areas of Dawa Chefa District, Northeastern Ethiopia, January I to February I5, 202I ( $N=409)$

\begin{tabular}{|c|c|c|c|c|}
\hline \multirow{2}{*}{\multicolumn{3}{|c|}{ Variables }} & \multicolumn{2}{|c|}{ Responses } \\
\hline & & & $\begin{array}{l}\text { Correct } \\
(\mathrm{n}[\%])\end{array}$ & $\begin{array}{l}\text { Incorrect } \\
(\mathrm{n}[\%])\end{array}$ \\
\hline \multicolumn{3}{|c|}{ COVID-19 is a bacterial borne diseases } & $338(82.6)$ & $7 I(17.4)$ \\
\hline \multicolumn{3}{|c|}{$\begin{array}{l}\text { Fever is one of the clinical symptoms of } \\
\text { COVID-19 }\end{array}$} & $331(80.9)$ & $78(19.1)$ \\
\hline \multicolumn{3}{|c|}{$\begin{array}{l}\text { Fatigue is one of the clinical symptoms of } \\
\text { COVID-19 }\end{array}$} & $354(86.6)$ & $55(\mid 3.4)$ \\
\hline \multicolumn{3}{|c|}{ Dry cough is a common feature of COVID-19 } & $355(86.8)$ & $54(13.2)$ \\
\hline \multicolumn{3}{|c|}{$\begin{array}{l}\text { An individual infected/suspected with } \\
\text { COVID-19 can show myalgia }\end{array}$} & $323(79.0)$ & $86(21.0)$ \\
\hline \multicolumn{3}{|c|}{$\begin{array}{l}\text { The disease is more dangerous in people } \\
\text { with cancer, diabetes, and chronic } \\
\text { respiratory diseases }\end{array}$} & $35 I(85.8)$ & $58(\mid 4.2)$ \\
\hline \multicolumn{3}{|c|}{$\begin{array}{l}\text { The disease can be transmitted directly } \\
\text { through the consumption of uncooked dairy } \\
\text { and meat products }\end{array}$} & $342(83.6)$ & $67(16.4)$ \\
\hline \multicolumn{3}{|c|}{ There is effective vaccine for COVID-19 } & $359(87.8)$ & $50(12.2)$ \\
\hline \multicolumn{3}{|c|}{$\begin{array}{l}\text { There is no cure for COVID-19, but } \\
\text { supportive treatment helps to recover }\end{array}$} & $354(86.6)$ & $55(\mid 3.4)$ \\
\hline \multicolumn{3}{|c|}{$\begin{array}{l}\text { Eating or contacting animal would result in } \\
\text { COVID-19 infection }\end{array}$} & $346(84.6)$ & $63(15.4)$ \\
\hline \multicolumn{3}{|c|}{$\begin{array}{l}\text { Persons with COVID-19 cannot infect the } \\
\text { virus to others when fever is not present }\end{array}$} & $30 \mathrm{I}(73.6)$ & $108(26.4)$ \\
\hline \multicolumn{3}{|c|}{$\begin{array}{l}\text { The COVID-19 can spreads via respiratory } \\
\text { droplets of infected individuals }\end{array}$} & $346(84.6)$ & $63(15.4)$ \\
\hline \multicolumn{3}{|c|}{$\begin{array}{l}\text { Young adults and children are not } \\
\text { responsible to prevent COVID-19, as they } \\
\text { are child }\end{array}$} & 293(71.6) & $116(28.4)$ \\
\hline \multicolumn{3}{|c|}{$\begin{array}{l}\text { Avoid going to crowded places can help to } \\
\text { reduce exposure to COVID-19 }\end{array}$} & $336(82.2)$ & $73(17.8)$ \\
\hline \multicolumn{3}{|c|}{$\begin{array}{l}\text { Washing hands regularly using water and } \\
\text { soap can help to prevent COVID-19 }\end{array}$} & $324(79.2)$ & $85(20.8)$ \\
\hline \multicolumn{3}{|c|}{$\begin{array}{l}\text { Physical distancing can reduce the risk of } \\
\text { COVID-19 if it is maintained less than two } \\
\text { meter }\end{array}$} & $308(75.3)$ & $101(24.7)$ \\
\hline \multirow{2}{*}{\multicolumn{3}{|c|}{$\begin{array}{l}\text { The COVID-19 can spreads through } \\
\text { touching coins and bankbooks } \\
\text { The ideal length of time to wash hands in } \\
\text { preventing the spread of COVID- } 19 \text { is } 20 \\
\text { seconds }\end{array}$}} & $334(81.7)$ & $75(18.3)$ \\
\hline & & & $338(82.6)$ & $7 I(17.4)$ \\
\hline \multicolumn{5}{|c|}{ Overall mean knowledge score $=82.3 \pm 9.6 \%$} \\
\hline $\begin{array}{l}\text { Knowledge } \\
\text { about } \\
\text { COVID-19 }\end{array}$ & $\begin{array}{l}\text { Satisfactory } \\
\text { Unsatisfactory }\end{array}$ & $\begin{array}{l}63.6 \% \\
(95 \% \mathrm{Cl}: \\
58.7-67.7) \\
36.4 \% \\
(95 \% \mathrm{Cl}: \\
32.3-41.3)\end{array}$ & & \\
\hline
\end{tabular}


Table 4 Attitude of Farmers towards COVID-19 in Peri-Urban Areas of Dawa Chefa District Northeastern Ethiopia, January I to February I5, 202I ( $\mathrm{N}=409)$

\begin{tabular}{|c|c|c|c|c|}
\hline \multirow{2}{*}{\multicolumn{2}{|c|}{ Variables }} & \multicolumn{3}{|c|}{ Responses } \\
\hline & & $\begin{array}{l}\text { Disagree } \\
(\mathrm{n}[\%])\end{array}$ & Undecided (n[\%]) & $\begin{array}{l}\text { Agree } \\
(\mathrm{n}[\%])\end{array}$ \\
\hline \multirow{2}{*}{\multicolumn{2}{|c|}{$\begin{array}{l}\text { Avoiding placing fingers into the eyes, nose, and mouth would prevent the spread of COVID-19 } \\
\text { Coughing and sneezing into the elbow or within the clothing is a good practice in preventing the } \\
\text { spread of COVID-19 }\end{array}$}} & $100(24.4)$ & $54(13.2)$ & $255(62.4)$ \\
\hline & & $105(25.7)$ & $5 I(12.5)$ & $253(61.8)$ \\
\hline \multirow{3}{*}{\multicolumn{2}{|c|}{$\begin{array}{l}\text { Daily temperature monitoring is useful to prevent the risk of contracting the virus } \\
\text { It is my opinion that early detection of COVID-19 can improve treatment outcome } \\
\text { Strictly following physical distancing measures and avoiding crowded places would limit the } \\
\text { spread of COVID-19 }\end{array}$}} & $117(28.6)$ & $30(7.3)$ & $262(64.1)$ \\
\hline & & $132(32.3)$ & $44(10.7)$ & $233(57.0)$ \\
\hline & & $145(35.4)$ & $44(10.8)$ & $220(53.8)$ \\
\hline \multicolumn{2}{|c|}{ It is my opinion that health education can help prevent COVID-19 } & $102(25.0)$ & $4 I(10)$ & $266(65.0)$ \\
\hline \multicolumn{2}{|c|}{ It is my opinion that COVID-19 is a curable disease } & $307(75.0)$ & $58(\mid 4.2)$ & $44(10.8)$ \\
\hline \multicolumn{2}{|c|}{ It is my opinion that authorities should quarantine COVID-19 patients in special hospitals } & $5 I(12.5)$ & $34(8.3)$ & $324(79.2)$ \\
\hline \multicolumn{2}{|c|}{ Proper usage of face mask should include covering nose, mouth, and chin } & $82(20.0)$ & $33(8.1)$ & 294(71.9) \\
\hline \multicolumn{2}{|c|}{ Staying at home would play a significant role in preventing the spread of COVID-19 } & $91(22.2)$ & $26(6.4)$ & 292(71.4) \\
\hline \multicolumn{2}{|c|}{$\begin{array}{l}\text { I will report to the immediate health institution or call } 8335 / 994 \text { If I suspect myself for COVID- } \\
19\end{array}$} & $34(8.3)$ & $46(11.3)$ & $329(80.4)$ \\
\hline \multicolumn{2}{|c|}{ If there is an available vaccine for the virus, I am willing to get it } & $36(8.8)$ & $7 I(17.4)$ & $302(73.8)$ \\
\hline \multicolumn{2}{|c|}{ I usually follow the updates about the spread of the virus in my country } & $33(8.0)$ & $53(13.0)$ & $323(79.0)$ \\
\hline \multicolumn{2}{|c|}{ I usually follow the updates about the spread of the virus worldwide } & $25(6.1)$ & $58(\mid 4.2)$ & $326(79.7)$ \\
\hline \multirow{2}{*}{\multicolumn{2}{|c|}{$\begin{array}{l}\text { If a lecture about the virus is organized near me, I will attend it } \\
\text { If flyers or brochures that include information about the disease are distributed, I will read them } \\
\text { and follow the instructions mentioned in them }\end{array}$}} & $22(5.4)$ & $60(14.7)$ & $327(79.9)$ \\
\hline & & $13(3.2)$ & $64(15.6)$ & $332(81.2)$ \\
\hline \multicolumn{2}{|c|}{ If protective measures and equipment are available at an affordable price, I will buy them } & $32(7.8)$ & $6 I(14.9)$ & $316(77.3)$ \\
\hline \multicolumn{5}{|c|}{ Overall mean attitude score $($ Mean $\pm S D)=77.3 \pm 9.3$} \\
\hline Attitude towards COVID-19 & $\begin{array}{l}\text { Positive }=38.4 \%(95 \% \mathrm{Cl}: 33.8-43.0) \\
\text { Negative }=61.6 \%(95 \% \mathrm{Cl}: 57.0-66.2)\end{array}$ & & & \\
\hline
\end{tabular}

respondents often wash their hands with soap for at least 20 seconds. Almost similar percentages of the respondents use a face mask and avoid kissing and contacting others. About half of them often go to the health institution if they get a fever, headache, and breathing problems. The overall mean practice score of the respondents was $70.6 \pm 13.2 \%$. Less than one-third $117(28.6 \%)$ of the respondents had good COVID-19 prevention practices (Table 5).

\section{Factors Affecting COVID-19 Prevention Practices}

From the bi-variable analysis, we found that age, educational status, income level, family size, receiving COVID-19 information from family or friends, receiving COVID-19 information from TV or radio, and receiving COVID-19 information from social media were the candidate variables for the multivariable logistic regression analysis. Multivariable logistic regression analysis revealed that respondents' age, educational level, and monthly income were all significantly associated $(\mathrm{p}<0.05)$ with COVID-19 prevention practices. The analysis indicated that respondents aged greater than or equal to 45 years old were 3.2 times more likely to apply good COVID-19 prevention practices compared to those whose ages ranged from 18 to 24 years. Those who completed secondary school were 3.1 times more likely to have good COVID-19 prevention practices than those who cannot read and write. Respondents who had a monthly income greater than or equal to 2,001.00 ETB were 1.9 times more likely to apply better COVID-19 prevention practices than those who had less than or equal to 499.00 ETB (Table 6). 
Table 5 COVID-19 Prevention Practices Among Farmers in Peri-Urban Areas of Dawa Chefa District Northeastern Ethiopia, January I to February I5, 2021 ( $N=409)$

\begin{tabular}{|c|c|c|c|c|}
\hline \multirow{2}{*}{\multicolumn{2}{|c|}{ Variables }} & \multicolumn{3}{|c|}{ Responses } \\
\hline & & $\begin{array}{l}\text { Often } \\
(\mathrm{n}[\%])\end{array}$ & $\begin{array}{l}\text { Sometimes } \\
(\mathrm{n}[\%])\end{array}$ & $\begin{array}{l}\text { Never } \\
\text { (n[\%]) }\end{array}$ \\
\hline \multicolumn{2}{|l|}{ Do you go to a crowded place? } & $188(46.0)$ & $62(15.1)$ & $159(38.9)$ \\
\hline \multicolumn{2}{|c|}{ To prevent contracting and spreading COVID-I9, I avoid consuming outdoor food. } & $233(57.0)$ & $97(23.7)$ & $79(19.3)$ \\
\hline \multicolumn{2}{|c|}{ To prevent contracting and spreading COVID-I9, I avoid public transportations (taxi, bus ... etc.) } & $290(70.9)$ & $60(14.7)$ & $59(14.4)$ \\
\hline \multicolumn{2}{|c|}{ Do you wash your hands with soap for at least 20 seconds? } & $253(61.8)$ & $107(26.2)$ & $49(12.0)$ \\
\hline \multicolumn{2}{|c|}{ To prevent contracting and spreading COVID-19, I pay more attention to my hygiene than usual } & $267(65.3)$ & $79(19.3)$ & $63(15.4)$ \\
\hline \multicolumn{2}{|c|}{ To prevent contracting and spreading COVID-19, I use facemasks } & $276(67.5)$ & $82(20.0)$ & $5 I(12.5)$ \\
\hline \multicolumn{2}{|c|}{ To prevent contracting and spreading COVID- I9, I avoid kissing/contacting others } & $278(68.0)$ & $89(21.8)$ & $42(10.2)$ \\
\hline \multicolumn{2}{|c|}{ Do you use alcohol-based hand sanitizer, if water is not available? } & $267(65.3)$ & $92(22.5)$ & $50(12.2)$ \\
\hline \multicolumn{2}{|c|}{ Do you participate in COVID-19 voluntary service in your community? } & $233(57.0)$ & $84(20.5)$ & $92(22.5)$ \\
\hline \multicolumn{2}{|c|}{ Do you go to a health institution, if you get a fever, headache, and breathing problem? } & $217(53.1)$ & $136(33.2)$ & $56(13.7)$ \\
\hline \multicolumn{2}{|c|}{ To prevent contracting and spreading COVID-19, I avoid going out of my home. } & 198(48.4) & $|2|(29.6)$ & $90(22.0)$ \\
\hline \multicolumn{5}{|c|}{ Overall mean practice score $=70.6 \pm 13.2 \%$} \\
\hline COVID-19 prevention practices & $\begin{array}{l}\text { Good }=28.6 \%(95 \% \mathrm{Cl}: 24.2-33.0) \\
\text { Poor }=71.4 \%(95 \% \mathrm{Cl}: 67.0-75.8)\end{array}$ & & & \\
\hline
\end{tabular}

\section{Discussion}

Despite repeated attempts to prevent and control COVID19 , the problem persists, harming the lives and economic progress of millions of people across worldwide, including Ethiopia. Lack of studies to identify the status of COVID19 prevention practices and assoicated factors in periurban areas in northeastern Ethiopia hinders the efforts of the prevention programs towards COVID-19. ${ }^{3}$

Having sufficient knowledge of COVID-19 is beneficial in gaining a clear understanding of the disease burden, which allows a person to take appropriate prevention practices. $^{22}$ The current study found that $63.6 \%(95 \% \mathrm{CI}$; 58.7-67.7) of the respondents had satisfactory knowledge, which is almost similar to a study conducted in Africa, which found that $61.6 \%$ of the study participants had a satisfactory knowledge. ${ }^{14}$ The majority of those who took part in this study were aware of the main COVID-19 transmission routes as well as the fact that there is no effective COVID-19 cure. The current figure, however, is lower than that of an Indian survey, which indicated that around $70 \%$ of respondents possessed satisfactory knowledge. ${ }^{23}$ This can be credited to India's health ministry's concerted attempts to inform the people about the pandemic's scope and severity, as well as its transmission, prevention, and control techniques. In addition, the average mean knowledge score of the respondents was $82.3 \%$, which is consistent with a survey conducted in Saudi Arabia, ${ }^{24}$, and Vietnam, ${ }^{3}$ where the mean knowledge score of the respondents was found to be $81.6 \%$ and $81.7 \%$, respectively. Measures such as mass education and providing training programs for those who are in need should be taken to improve the level of knowledge among respondents. However, the higher result was reported in Pakistan and India where the mean knowledge score of the respondents was $90 \%$ and $88.9 \%$, respectively. ${ }^{6,8}$ A slightly lower results was reported in China in which the overall mean knowledge score of the respondents was $80 \%{ }^{25}$

People's attitude affect their decision to do or not do something, and having a positive attitude means that they are eager, capable, and committed to taking various prevention steps to avoid contracting COVID-19 infection. According to the findings, $38.4 \%$ (95\% CI: $33.8-43.0)$ of the respondents had a positive attitude towards COVID19 , which was almost a half lower than the study done in Pakistan where $80-90 \%$ of the respondents had a positive attitude towards COVID- $19^{8}$ and consistent with the study done in China. ${ }^{11}$ In addition, the respondents' overall mean attitude score was $77.3 \%$, which is consistent with the study conducted in India, ${ }^{6}$ where the mean attitude score of the respondents was $73.3 \%$. The higher result was reported in China ${ }^{25}$ and Saudi Arabia, ${ }^{24}$ where the 
Table 6 Factors Affecting COVID-19 Prevention Practices Among Farmers in Peri-Urban Areas of Dawa Chefa District, Northeastern, Ethiopia, January I to February I5, 2021 ( $N=409)$

\begin{tabular}{|c|c|c|c|c|c|}
\hline \multirow[t]{2}{*}{ Variables } & \multicolumn{2}{|c|}{ Prevention Practices of COVID-19 } & \multirow[t]{2}{*}{ COR $(95 \% \mathrm{Cl})$} & \multirow[t]{2}{*}{ AOR $(95 \% \mathrm{Cl})$} & \multirow[t]{2}{*}{$P$-value } \\
\hline & Good (n[\%]) & Poor (n[\%]) & & & \\
\hline $\begin{array}{l}\text { Age } \\
\qquad \begin{array}{l}18-24 \\
25-34 \\
35-44 \\
\geq 45\end{array}\end{array}$ & $\begin{array}{l}33(28.2) \\
13(11.1) \\
32(27.4) \\
39(33.3)\end{array}$ & $\begin{array}{l}93(31.8) \\
84(28.8) \\
78(26.7) \\
37(12.7)\end{array}$ & $\begin{array}{l}\text { I } \\
0.4(0.2-0.9) \\
1.2(0.7-2.0) \\
3.0(1.6-5.4)\end{array}$ & $\begin{array}{l}0.5(0.2-0.9) \\
1.2(0.7-2.3) \\
3.2(1.7-6.1)\end{array}$ & $\begin{array}{l}\leq 0.00 I^{*} \\
0.037 \\
0.527 \\
\leq 0.001\end{array}$ \\
\hline $\begin{array}{l}\text { Educational status } \\
\text { Cannot read and write } \\
\text { Can read and write } \\
\text { Primary (I-8 grade) } \\
\text { Secondary (9-12) }\end{array}$ & $\begin{array}{l}35(29.9) \\
31(26.5) \\
18(15.4) \\
33(28.2)\end{array}$ & $\begin{array}{l}100(34.2) \\
126(43.2) \\
42(14.4) \\
24(8.2)\end{array}$ & $\begin{array}{l}1 \\
0.7(0.4-1.2) \\
1.2(0.6-2.4) \\
3.9(2.0-7.5)\end{array}$ & $\begin{array}{l}0.7(0.4-1.2) \\
1.0(0.5-2.2) \\
3.1(1.4-6.6)\end{array}$ & $\begin{array}{l}0.001 * \\
0.166 \\
0.914 \\
0.004\end{array}$ \\
\hline $\begin{array}{l}\text { Monthly income level (ETB) } \\
\quad \leq 499.00 \\
500-2,000.00 \\
\geq 2,001.00\end{array}$ & $\begin{array}{l}39(33.3) \\
33(28.2) \\
45(38.5)\end{array}$ & $\begin{array}{l}119(40.7) \\
110(37.7) \\
63(21.6)\end{array}$ & $\begin{array}{l}1 \\
0.9(0.5-1.6) \\
2.2(1.3-3.7)\end{array}$ & $\begin{array}{l}0.7(0.4-1.3) \\
1.9(1.1-3.4)\end{array}$ & $\begin{array}{l}0.008^{*} \\
0.319 \\
0.031\end{array}$ \\
\hline $\begin{array}{l}\text { Family size } \\
\qquad 5 \\
>5\end{array}$ & $\begin{array}{l}68(58.1) \\
49(41.9)\end{array}$ & $\begin{array}{l}\mid 47(50.3) \\
\mid 45(49.7)\end{array}$ & $\begin{array}{l}\text { I } \\
0.7(0.5-1.1)\end{array}$ & $1.6(I . I-2.5)$ & 0.072 \\
\hline $\begin{array}{l}\text { Receiving information through family/friends } \\
\text { No } \\
\text { Yes }\end{array}$ & $\begin{array}{l}53(45.3) \\
64(54.7)\end{array}$ & $\begin{array}{l}157(53.8) \\
135(46.2)\end{array}$ & $\begin{array}{l}\text { I } \\
0.1(0.5-1.1)\end{array}$ & $0.7(0.5-1.2)$ & 0.195 \\
\hline $\begin{array}{l}\text { Receiving information through social media } \\
\text { No } \\
\text { Yes }\end{array}$ & $\begin{array}{l}81(69.2) \\
36(30.8)\end{array}$ & $\begin{array}{l}220(75.3) \\
72(24.7)\end{array}$ & $\begin{array}{l}1 \\
0.7(0.5-1.2)\end{array}$ & $0.9(0.5-1.7)$ & 0.836 \\
\hline $\begin{array}{l}\text { Receiving information through TV/radio } \\
\text { No } \\
\text { Yes }\end{array}$ & $\begin{array}{l}54(46.2) \\
63(53.8)\end{array}$ & $\begin{array}{l}157(53.8) \\
135(46.2)\end{array}$ & $\begin{array}{l}\text { I } \\
0.7(0.5-1.1)\end{array}$ & $0.7(0.4-I . I)$ & 0.150 \\
\hline
\end{tabular}

Notes: *Significance difference at $p<0.05$.

Abbreviation: ETB, Ethiopian Birr.

mean attitude score of the respondents is reported to be $85.4 \%$ and $94.1 \%$ respectively. Without a positive mindset, learning about the transmission and mitigation methods is useless for any interventions aimed at reducing the pandemic's health and economic effects. As a result, a strategy should be devised to shift the respondent's thinking and prepare them to correctly implement the numerous prevention measures in order to protect themselves and their families from the risk of COVID-19 exposure.

Due to a shortage of effective treatment procedures and an enough budget to deliver vaccines for all people, especially in poor countries like Ethiopia; more effort is needed to focus on the holistic preventive strategy. In this survey, less than a third, $28.6 \%$ (95\% CI: 24.2-33.0) of the respondents had a good
COVID-19 prevention practice. This figure was lower than the study conducted in Pakistan, where nearly all participants perform the basic prevention practices. ${ }^{8}$ In Jordan, $87.5 \%$ of respondents had good COVID-19 prevention practices, which included hand washing with soap or alcohol, wearing personal protective equipment, and wearing a mask. ${ }^{1}$

Lower COVID-19 prevention practices found in this study may be attributed to a lack of sufficient public education, community carelessness in implementing various prevention practices, a negative attitude toward the pandemic, and most importantly, the absence of clear legal issues that suggest what to do and what not to do in terms of pandemic control. Furthermore, the respondents' overall mean practice score was $70.6 \%$, which is lower than a study done in Saudi 
Arabia, where the respondents' mean practice score was $86.8 \%{ }^{24}$ A higher result was also reported in India, ${ }^{6}$ where the mean practice score of the respondents was $93.0 \%$, and China in which about $90 \%$ of the study subjects had a good COVID-19 prevention practices. $^{25}$ Appropriate preventive initiatives will help to save millions of people's lives and reduce the cost of medicine and supportive care.

The current study also found that individuals aged 45 and up were 3.2 times more likely to apply good COVID-19 prevention practice than those aged 18 to 24 years (AOR: 3.2; 95\% CI; 1.7-6.1). The current result is in line with the research conducted in Egypt, India, Jordan, Bangladesh, Gondar, and Dire Dawa City administration. 5,6,9,10,13,26 Because the elderly have a larger chance of contracting and developing complications from the diseases, they used better preventative strategies. $^{15}$

The survey also found that people with a secondary education or higher were 3.1 times more likely to apply good prevention practices than those who could not read or write (AOR: 3.1; 95\% CI: 1.4-6.6). This finding is supported by the study done in $\operatorname{Jordan}^{5}$ and Bangladeshi, ${ }^{16}$ where higher education is associated with good COVID-19 prevention practices.

Moreover, the study found that respondents having a monthly income of greater than or equal to 2,001.00 ETB were 1.9 times more likely to employ better COVID-19 prevention practices than those who had a monthly income of less than or equal to 499 ETB (AOR: 1.9; 95\% CI; 1.1-3.4). The present finding is consistent with the study done in $\mathrm{Egypt}^{10}$ and Bangladeshi, ${ }^{16}$ where poor income was associated with poor COVID-19 prevention practices. This suggests that a lack of sufficient income to carry out various prevention practices is an obstacle to lowering the risk of infection. ${ }^{15}$

\section{Conclusion}

Even though the majority of farmers had satisfactory knowledge, the survey found that a considerable proportion of them had a negative attitude and poor COVID-19 prevention practices. Age, educational status, and monthly income of the respondents were significantly associated $(p<0.05)$ with COVID-19 prevention practices. As a result, steps should be taken to improve the attitudes, educational status, and income level of the farmers to minimize the risk of COVID-19 exposure. This can be achieved by informing the vulnerable population, which may be at risk of contracting COVID-19, about the pandemic's seriousness and political, social, economic, and health consequences on a regular and timely basis. For those who cannot afford it, hand sanitizer and a face mask should be given. Vaccines should also be available for the elderly.

\section{Ethical Consideration}

All of the methods used in this study were done following the Helsinki declaration. As a result, ethical clearance was obtained from the ethical review board of Wollo University College of Medicine and Health Science. A formal letter of cooperation was also written to the town administration. Because not all of the study participants were educated, obtaining written consent from them was difficult. As a result, after receiving ethical review board permission, verbal consent was received from study participants. Before starting the interview, the data collector explained the purpose of the study for all the participants, and verbal consent was obtained from the study participants. During data collection, individuals with COVID-19 symptoms were linked to the surrounding health institution for screening and further treatment. All the information obtained from each study participant was kept confidential.

\section{Acknowledgment}

First, the authors wish to express their gratitude to Wollo University's College of Medicine and Health Sciences for providing the funds necessary to duplicate the data collection tool. The authors would like to express their gratitude to the Dawa Chefa District Administration for providing the necessary information required to conduct the study. Finally, the authors would like to express their gratitude to the data collectors, supervisors, and participants in the research.

\section{Author's Contributions}

All authors made a significant contribution to the work reported, whether that is in the conception, study design, execution, acquisition of data, analysis, and interpretation, or in all these areas; took part in drafting, revising, or critically reviewing the article; gave final approval of the version to be published; have agreed on the journal to which the article has been submitted; and agree to be accountable for all aspects of the work.

\section{Disclosure}

The authors report no conflicts of interest in this work.

\section{References}

1. Khader Y, Al Nsour M, Al-Batayneh OB, et al. Dentists' awareness, perception, and attitude regarding COVID-19 and infection control: Cross-sectional study among Jordanian dentists. JMIR Public Health Surveill. 2020;6(2):1-7. doi:10.2196/18798 
2. Schoeman D, Fielding BC. Coronavirus envelope protein: current knowledge. Virol J. 2019;16(69):1-22.

3. Giao H, Han NTN, Khanh TV, Ngan VK, Tam VV, Le An P. Knowledge and attitude toward COVID-19 among healthcare workers at District 2 Hospital, Ho Chi Minh City. Asian Pac J Trop Med. 2020;13(6):260-265. doi:10.4103/1995-7645.280396

4. Adhikari SP, Meng S, Wu YJ, et al. Epidemiology, causes, clinical manifestation and diagnosis, prevention and control of coronavirus disease (COVID-19) during the early outbreak period: a scoping review. Infect Dis Poverty. 2020;9(1):1-12. doi:10.1186/s40249-020-00646-x

5. Elayeh E, Aleidi SM, Ya'acoub R, Haddadin RN, Mallhi TH. Before and after case reporting: a comparison of the knowledge, attitude and practices of the Jordanian population towards COVID-19. PLoS One. 2020;15(10):1-17. doi:10.1371/journal.pone. 0240780

6. Yousaf MA, Noreen M, Saleem T, Yousaf I. A cross-sectional survey of Knowledge, Attitude, and Practices (KAP) toward pandemic COVID-19 among the general population of Jammu and Kashmir, India. Soc Work Public Health. 2020;35(7):569-578. doi:10.1080/ 19371918.2020.1806983

7. Huang C, Wang Y, Li X, et al. Clinical features of patients infected with 2019 novel coronavirus in Wuhan, China. Lancet. 2020;395 (10223):497-506. doi:10.1016/S0140-6736(20)30183-5

8. Hussain I, Majeed A, Imran I, et al. Knowledge, attitude, and practices toward COVID-19 in primary healthcare providers: a Cross-Sectional Study from three tertiary care hospitals of Peshawar, Pakistan. J Community Health. 2020;0123456789.

9. Amsalu B, Guta A, Seyoum Z, et al. Practice of COVID-19 prevention measures and associated factors among residents of Dire Dawa City, Eastern Ethiopia: Community-Based Study. J Multidiscip Healthc. 2021;14:219-228. doi:10.2147/JMDH.S292409

10. Kasemy ZA, Bahbah WA, Zewain SK, et al. Knowledge, attitude and practice toward COVID-19 among Egyptians. J Epidemiol Glob Health. 2020;10(4):378-385. doi:10.2991/jegh.k.200909.001

11. Zhong BL, Luo W, Li HM, et al. Knowledge, attitudes, and practices towards COVID-19 among Chinese residents during the rapid rise period of the COVID-19 outbreak: a quick online cross-sectional survey. Int J Biol Sci. 2020;16(10):1745-1752. doi:10.7150/ijbs.45221

12. Hung L. The SARS epidemic in Hong Kong. What lessons have we learned? J R Soc Med. 2003;57(9):652-654.

13. Islam S, Emran GI, Rahman E, et al. Knowledge, attitudes and practices associated with the COVID-19 among slum dwellers resided in Dhaka City: a Bangladeshi interview-based survey. J Public Health. 2020;1-13.

14. Hager E, Odetokun IA, Bolarinwa O, et al. Knowledge, attitude, and perceptions towards the 2019 coronavirus pandemic: a bi-national survey in Africa. PLoS One. 2020;15(7):1-13. doi:10.1371/journal.pone.0236918

15. Azlan AA, Hamzah MR, Sern TJ, Ayub SH, Mohamad E, Tu W-J. Public knowledge, attitudes and practices towards COVID-19: a cross-sectional study in Malaysia. PLoS One. 2020;15(5):1-15. doi:10.1371/journal.pone. 0233668
16. Ferdous Z, Islam S, Sikder T, Mosaddek AS, Zegarra-Valdivia JA, Gozal D. Knowledge, attitude, and practice regarding COVID-19 outbreak in Bangladesh: an online-based cross-sectional study. PLoS One. 2020;15(10):1-17. doi:10.1371/journal.pone.0239254

17. Jalloh MF, Robinson SJ, Corker J, et al. Knowledge, attitudes, and practices related to ebola virus disease at the end of a national epidemic - guinea, August 2015. MMWR Morb Mortal Wkly Rep. 2017;66(41):1109-1115. doi:10.15585/mmwr.mm6641a4

18. Agropecuarias FC, Trujillo UN, Pablo AJ. What is the impact of COVID-19 disease on agriculture? Sci Agropecu. 2020;11(1):3-6. doi:10.17268/sci.agropecu.2020.01.00

19. Central Statistical Agency. Federal democratic Republic of Ethiopia central statistical agency population projection of Ethiopia for all regions at wereda level from 2014-2017. 2017. Available from: www.academia.edu>30252151>Federal_ Democratic. Accessed March, 2021.

20. Amakelew S, Eshetu M, Animut G, Gebeyaw K. Microbial quality of cow milk in Dawa Chefa District, Amhara Region. Adv Dairy Res. 2015;3(2):1-4.

21. Ekpenyong B, Obinwanne CJ, Ovenseri-Ogbomo G, et al. Assessment of knowledge, practice and guidelines towards the novel COVID-19 among eye care practitioners in Nigeria-a Survey-Based Study. Int J Environ Res Public Health. 2020;17 (14):1-12. doi:10.3390/ijerph17145141

22. Reuben RC, Danladi MMA, Saleh DA, Ejembi PE. Knowledge, attitudes, and practices towards COVID-19: an epidemiological survey in North-Central Nigeria. J Community Health. 2020;1-14. doi:10.1007/s10900-019-00710-0

23. Mbroh LA. Assessing knowledge, attitude, and practices of hand hygiene among university students. Public Health. 2019;232. Available from: https://cornerstone.lib.mnsu.edu/etdshttps://corner stone.lib.mnsu.edu/etds/950. Accessed April, 2021

24. Al-Hanawi MK, Angawi K, Alshareef N, et al. Knowledge, attitude and practice toward COVID-19 among the public in the Kingdom of Saudi Arabia: a Cross-Sectional Study. Front Public Health. 2020;8 (217):1-10. doi:10.3389/fpubh.2020.00217

25. Peng Y, Pei C, Zheng Y, et al. Knowledge, attitude and practice associated with COVID-19 among university students: a cross-sectional survey in China. BMC Public Health. 2020;20 (1292):1-8. doi:10.1186/s12889-020-09392-z

26. Asmelash D, Fasil A, Tegegne Y, Akalu TY, Ferede HA, Aynalem GL. Knowledge, attitudes, and practices toward prevention and early detection of COVID-19 and associated factors among religious clerics and traditional healers in Gondar town, northwest Ethiopia: a community-based study. Risk Manag Healthc Policy. 2020;13:2239-2250. doi:10.2147/RMHP.S277846
Journal of Multidisciplinary Healthcare

\section{Publish your work in this journal}

The Journal of Multidisciplinary Healthcare is an international, peerreviewed open-access journal that aims to represent and publish research in healthcare areas delivered by practitioners of different disciplines. This includes studies and reviews conducted by multidisciplinary teams as well as research which evaluates the results or conduct of such teams or healthcare processes in general. The journal covers a very wide range of areas and welcomes submissions from practitioners at all levels, from all over the world. The manuscript management system is completely online and includes a very quick and fair peer-review system. Visit http://www.dovepress.com/testimonials. php to read real quotes from published authors. 